\title{
EFFECTS OF PHYSICAL ACTIVITY IN MUSCLE ULTRASOUND EVALUATION OF AN OLDER ADULT POPULATION - A PILOT STUDY
}

\author{
Efeitos da atividade física na avaliação ecogrática muscular \\ de uma população idosa - estudo piloto
}

\author{
Rute Santos ${ }^{\mathrm{a}, \mathrm{b}}\left(\mathbb{D}\right.$, Helena Ferraz ${ }^{\mathrm{C}}$ (1)
}

INTRODUCTION: Insufficient physical activity levels in aging populations have become an increasing challenge. The phenotype of sarcopenia has many causes in addition to aging. The presence of low muscle performance is necessary for diagnosis, in addition to low muscle mass. The ultrasound is an imaging modality with several advantages, making it potentially useful in assessing muscle changes. OBJECTIVE: This pilot study aimed to evaluate muscle morphology changes in older adults after a physical activity program using ultrasound parameters. METHODS: Older adults aged over 60 years were divided into two non-randomized groups in an unblinded trial: an intervention group $(n=18)$, who took part in a physical activity program for 8 weeks; and a control group, whose members were encouraged to maintain their usual daily routines $(n=16)$. All the participants were submitted to bilateral quadriceps muscle ultrasound evaluations; the thickness and echo-intensity muscles were analyzed. Only six participants of each group were available for a second evaluation session. The t-test for independent samples was used to evaluate differences between the groups. A t-test for paired samples was performed for the IntG at baseline and post-intervention. RESULTS: Muscle thickness showed a negative correlation with age, while echo-intensity showed a positive correlation. Echo-intensity showed a negative correlation with muscle thickness. There were differences between the groups for both measurement. CONCLUSIONS: A change in muscle morphology was noticeable when a physical activity program was applied in this pilot study. New studies are necessary to confirm these preliminary findings. Ultrasound could be a low-cost objective method for muscle evaluation in physical activity programs assessment in older adults. KEYWORDS: aging; quadriceps muscle, physical activity.

INTRODUÇÃO: Níveis insuficientes de atividade física em populações idosas têm-se tornado um desafio crescente. O fenótipo da sarcopenia pode ter muitas causas além do envelhecimento. A presença de baixo desempenho muscular é necessária para o diagnóstico, além da diminuição da massa muscular. A ecografia é uma modalidade de imagem com diversas vantagens, sendo potencialmente útil na avaliação das alterações musculares. OBJETIVO: Este estudo piloto teve como objetivo avaliar as alterações da morfologia muscular em idosos após um programa de atividade física por meio de parâmetros ecográficos. MÉTODOS: Idosos com mais de 60 anos foram divididos em dois grupos não randomizados em um ensaio não cego: um grupo de intervenção $(n=18)$, que participou de um programa de atividade física por 8 semanas; e um grupo controle, incentivado a manter a rotina diária usual $(n=16)$. Todos os participantes foram submetidos a avaliações ecográficas do músculo quadríceps bilateralmente; a espessura e a ecogenicidade dos músculos foram analisadas. Apenas seis participantes de cada grupo estavam disponíveis para uma segunda sessão de avaliação. O teste t para amostras independentes foi usado para avaliar as diferenças entre os grupos. Um teste t para amostras emparelhadas foi realizado para o IntG na linha de base e pósintervenção. RESULTADOS: A espessura muscular apresentou correlação negativa com a idade, enquanto a ecogenicidade apresentou correlação positiva. A ecogenicidade apresentou correlação negativa com a espessura muscular. Houve diferenças entre os grupos para as medidas. CONCLUSÕES: Alterações na morfologia muscular foram perceptível após a aplicação de um programa de atividade física, neste estudo piloto. No entanto, novos estudos são necessários para confirmar esses achados preliminares. A ecografia pode ser um método objetivo de baixo custo para avaliação muscular na verificação da eficácia de programas de atividade física em idosos.

PALAVRAS-CHAVE: envelhecimento; músculo quadríceps; exercício físico.

alnstituto Politécnico de Coimbra, Escola Superior de Tecnologia de Saúde de Coimbra, Departamento Imagem Médica e Radioterapia, Rua 5 de Outubro - SM Bispo, Apartado 7006, 3046-854 Coimbra

'Laboratório de Investigação Aplicada em Saúde (LabinSaúde), Rua 5 de Outubro - SM Bispo, Apartado 7006, 3046-854 Coimbra

'Hospital King's College Hospital NHS Foundation Trust, Denmark Hill, London

Correspondence data

Rute Santos - Rua 5 de Outubro, SM Bispo, Apartado 7006 - 3046-854 - Coimbra, Portugal. E-mail: rutesantos@estescoimbra.pt

Received on: 07/14/2020. Accepted on: 11/28/2020

How to cite this article: Santos R, Ferraz H. Effects of physical activity in muscle ultrasound evaluation of an older adult population - a pilot study. Geriatr Gerontol Aging. 2021;15:e0210006. https://doi.org/10.5327/Z2447-212320202000084

https://doi.org/10.5327/Z2447-212320202000084 


\section{INTRODUCTION}

Aging is a continuous process that includes a life cycle that goes from birth to death ${ }^{1}$ and brings profound social normality changes. ${ }^{2}$ Aging relates to a set of progressively accumulating changes affecting individuals' body structure and functions. It is also a stage of life during which morphological, psychological, hereditary, cultural, intellectual, racial, and other factors may have influences. ${ }^{3}$

From the physiological point of view, the aging process is marked by reduced motor skills, flexibility, strength, and speed, leading to difficulties performing daily activities and maintaining a healthy lifestyle. ${ }^{4}$

Several changes occur in the body during the aging process, especially in the musculoskeletal system. Sarcopenia is one of the most significant, consisting of the loss of strength and skeletal muscle mass quality. ${ }^{3,5,6}$ This phenomenon has a significant impact on public health due to its recognized functional consequences for walking and balance, increasing the risk of falling and loss of functional physical independence, compounded by an increased risk of chronic diseases such as diabetes and osteoporosis. ${ }^{5}$

Sarcopenia is a geriatric syndrome characterized by progressive and generalized loss of skeletal muscle mass and strength, with a risk of adverse outcomes such as physical disability, falls, low quality of life, and death. ${ }^{6-8}$.Its prevalence increases from $10 \%$ in those aged $60-70$ years to $30 \%$ in those over $80{ }^{8}$

Older adults with sarcopenia have a decrease in length, elasticity, and number of muscle fibers, as well as a loss of elasticity of tendons and ligaments, decrease in bone mineral content and bone formation, connective tissue proliferation and reduction in joint cartilage, basal metabolism rate, muscle strength, and daily physical activity levels. ${ }^{3}$ Moreover, the amount of non-contractile intramuscular tissue increases with aging. ${ }^{9}$

On the other hand, the muscle architecture may also change with aging. According to some authors, there is an approximately $10-16 \%$ decrease in the number of fascicles in the gastrocnemius muscle. The angle of pennation is $7-16 \%$ smaller in the older adult population than younger people. ${ }^{9}$ Several studies report changes in the specific strength of the gastrocnemius muscle, which is reduced in older adults, indicating that strength per unit area decreases with aging..$^{10}$ On the other hand, there is also a decrease in specific fiber tension, which is considered another factor contributing to muscle properties changes.

The reduction in fascicle length with aging suggests smaller numbers of serially arranged sarcomeres, which may have implications for the older adult population's muscles. ${ }^{9}$ However, it should be noted that the physiological manifestations of aging may not be solely caused by the aging process but may also be influenced by reduced use. ${ }^{9}$

Ultrasound (US) is a diagnostic imaging method that offers several advantages: being portable and not using ionizing radiation, for instance, enables evaluation in any location, including institutions or homes, reaching the entire population, ${ }^{11-14}$ enabling more effective and earlier diagnosis. ${ }^{13-16}$

Several parameters allow US to explore structures in detail, especially muscles. Thickness and echo-intensity (EI) are two parameters that can be measured quantitatively, revealing muscle quality; they both characterize muscle and can be used to evaluate changes induced by exercise, disease, or aging. ${ }^{12,13,17-20}$ Echo-intensity, assessed by US, is the tissue's capacity to reflect ultrasound waves and produce echoes, which may contain information on muscle tissue composition.

For example, in low-density tissues (and liquids), the facility with which ultrasound beam passes through the different structures results in a smaller proportion being reflected. Such anatomy appears hypoechogenic. When the opposite is true, i.e., when the US beam finds it more difficult to pass through structures (connective tissue and fat, for example), a more significant proportion is reflected, causing structures to appear hyperechogenic. A healthy muscle is seen on a US image as hypoechogenic, with hyperechogenic fibers. In contrast, inactive and pathological muscles, or those with degenerative aging processes, exhibit a different configuration, more hyperechogenic and more diffuse. Tendons' characteristics are the opposite; they are already hyperechogenic, and aging turns them more hypoechogenic. ${ }^{21,22}$

Yoshiko et al. ${ }^{23}$ showed that walking training may improve older individuals' muscle quality but that combining it with home-based resistance training has better results in increasing EI. Both muscle size and muscle quality improved with increasing numbers of weeks of a combined walking and home-based resistance training intervention. ${ }^{23}$

Several authors defend the great diversity of benefits associated with the practice of physical activity. These include increases in longevity, flexibility, functionality, and independence; maintenance of bone strength and well-being; improved sleep; weight control; decreased cardiovascular disease and risk of fractures; and reduced risk of depression and dementia. ${ }^{2,24-29}$

It is necessary and important to develop physical activity programs for the older adult to reap the motor skills benefits for carrying out daily living activities and improve well-being, health status, and quality of life. ${ }^{25,30}$ When choosing a physical activity program, it is important to consider some fundamental aspects, particularly the intensity, duration, frequency, and progression of physical activity. According to 
age, functional capacity, and other factors, the modality or exercise should be suitable for each participant. ${ }^{4}$

Additionally, physical activity aims to improve physical fitness, health promotion, and reduce risk factors for chronic diseases. ${ }^{4,24}$ Exercises of moderate-intensity based on aerobic activities and muscle strength improvement are recommended, and exercises that maintain or increase flexibility and balance to reduce sedentary lifestyle and prevent falling situations. ${ }^{24}$ However, a prior assessment of the older adult's health status and physical condition is essential, to develop a more specific program and effectively plan progressive activities. ${ }^{2,24}$

The implementation of physical activity programs has been growing, along with creating healthy lifestyle habits, such as regular practice of physical activity. ${ }^{2,27}$ It is essential to motivate and encourage regular physical activity in the older adult, emphasizing its several benefits and its positive outcomes for promoting health and quality of life., ${ }^{2,25}$

Several studies report that active older adults show improvements in well-being and physical fitness, suggesting that physical activity delays older adults' disability and dependence. ${ }^{2,24,30}$ The Otago Exercise Program (OTAGO) is usually employed in older adult physical activity programs. It combines moderate-intensity strength exercises focusing on the lower limbs and balance, to be performed for about 30 minutes at least three times a week. Walking on alternate days, at least twice a week, can also be featured. This program's results are very positive in increasing the balance, gait, and muscular strength of the lower limbs in older adults. ${ }^{31}$

The Aga@4life project is a multidisciplinary geriatric approach, aiming to promote active and healthy aging by implementing an integrated and tailored intervention program in a cohort of older adults, using the FallSensing Exergames, a wearable sensor-based exercise program based on OTAGO. ${ }^{31}$ It aims to promote active and healthy aging through validation and implementation of an innovative intervention model, based on the broad geriatric approach (AGA), incorporating endogenous resources from the region in the intervention plans, adding elements of technological innovation, resulting from the creation of remote digital monitoring platforms. This pilot study aimed to evaluate muscle morphology changes in older adults after a physical activity program using ultrasound parameters.

\section{METHODS}

Participants and ethics

Thirty-four individuals (intervention group $=18$; control group $=16$ ) of both genders, aged 60 years or over, without functional decline and with no prior history of cerebrovascular or neurological disorders, were invited to participate in an unblided and non-randomized experimental study in January 2018. According to the Declaration of Helsinki guidelines, the study was conducted and approved by the Research Ethics Committee at the Polytechnic Institute of Coimbra (No.6/2017). Anonymity and confidentiality of the data collected were assured, and all participants signed an informed consent form before admission.

\section{Procedure}

This pilot study examined the relationship between muscle architecture changes by ultrasonography and its association with a physical activity program's participation.

All the participants were recruited from a daycare center in Portugal, where they spend part of the day. During February and March 2018, an individual baseline multidisciplinary evaluation was performed, comprising demographic and clinical information: comorbidities, ongoing treatments, diet, physical activity profile, cardiovascular risk profile, functional ability, fear of falling, and history of falls in the previous 12 months.

Twenty eight participants aged over 60 years were registered to participate in a non-randomized experimental study. They were divided into two non-randomized groups in an unblinded trial according to their enthusiasm for participating in the study. The intervention group (IntG) $(n=18,13$ males and 5 females) participated in a program consisting of an exercise plan incorporated into a technological system using pressure and inertial sensors, feedback, and Exergames for eight weeks, three sessions a week with a duration of approximately $20 \mathrm{~min}$ on each occasion. ${ }^{31}$ The control group (ConG) ( $\mathrm{n}=16,13$ males and 3 females) was encouraged to maintain their usual daily routines (outdoor aerobic exercise). The progression of exercise intensity depended on participant feedback and recommendations of the original program.

\section{Ultrasound examination}

All participants underwent US evaluation of the three heads of the quadriceps femoris; vastus medialis (VM) (Figure 1A); vastus lateralis (VL) (Figure $1 \mathrm{~B})$, and rectus femoris $(\mathrm{RF})$ (Figure 1C), bilaterally. Both groups were evaluated at two sessions: at baseline and after 8 weeks of intervention. US images were acquired at $50 \%$ of the distance between the upper pole of the patella and the anterior iliac crest. ${ }^{32}$

Images were acquired in a supine position, using a General Electrics LOGIQe, with a linear-array transducer with variable frequency band (7-12 MHz). All system-setting parameters were optimized individually for each scanned muscle 
and recorded and kept constant during the session. A water-soluble gel was used to provide acoustic contact, and care was taken not to compress the dermal surface. Compression was minimal and applied in the vertical direction, avoiding anisotropy artifacts.

Values for muscle thickness (MT) and EI were obtained using Image J (National Institutes of Health, Bethesda, MD, USA) by the same operator. The MT was determined as the distance between the superficial fascia and each muscle's deep fascia (Figure 2A). ${ }^{13}$ A single image was saved
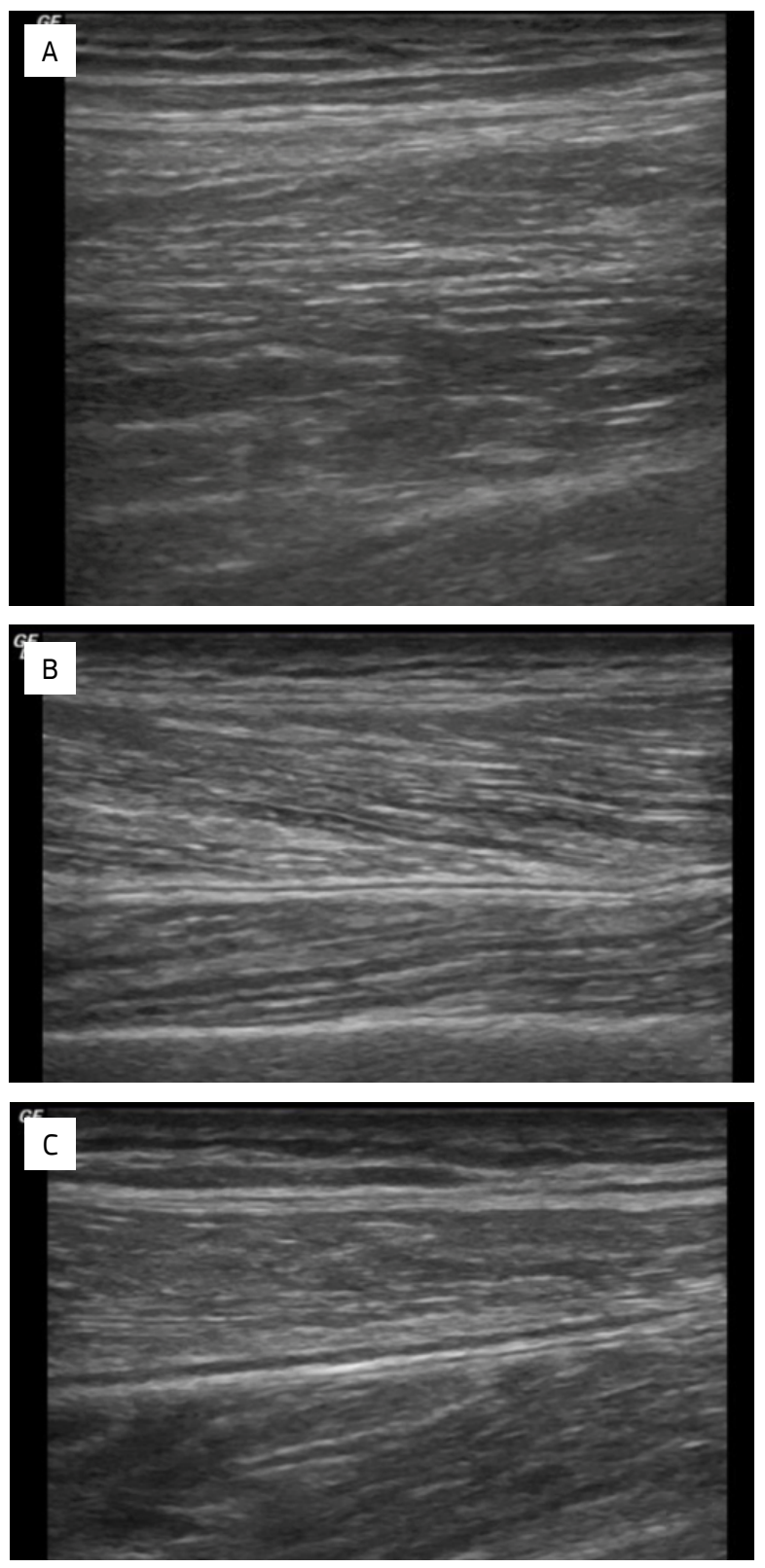

Figure 1. Ultrasound images of the three heads of the quadriceps muscle, in longitudinal view: (A) vastus medialis muscle; (B) vastus lateralis muscle; and $(\mathrm{C})$ rectus femoris muscle.

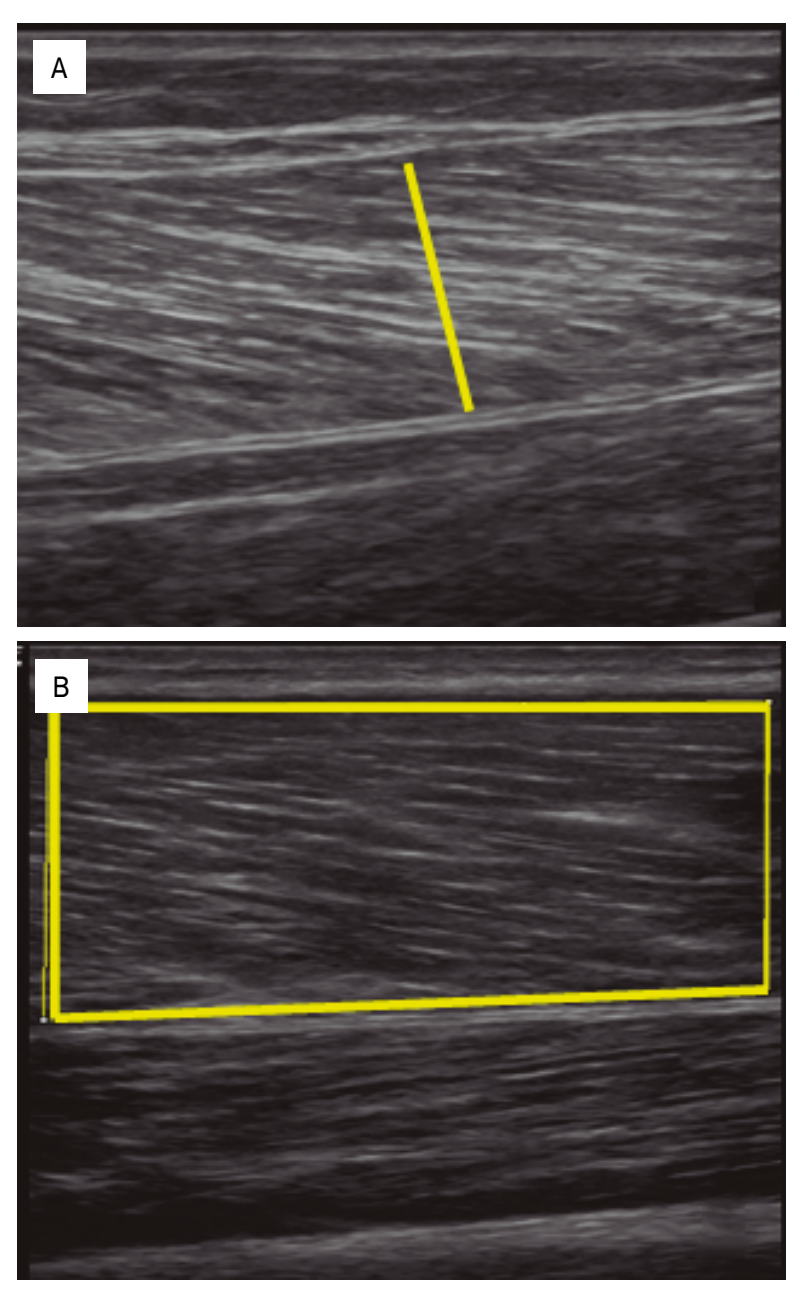

Figure 2. (A) Muscle thickness measurement, avoiding the superficial and deep fascias of the vastus lateralis; (B) muscle echo-intensity measurement, avoiding the superficial and deep fascias of the vastus lateralis, including a maximum of muscle.

for each muscle bilaterally, each thigh, in longitudinal view, making a total of 256 images. Regions of interest, including as much muscle as possible but avoiding bone and surrounding fascia (Figure 2B), were selected for calculation of $\mathrm{EI}$, and the mean EI of each muscle was determined using a standard histogram grayscale with a value ranging from 0 (black) to 255 (white). ${ }^{13}$

\section{Statistical analysis}

Statistical analysis was performed using SPSS version 26.0. Data was reported as mean \pm standard deviation (SD). The normality was determined with the Shapiro-Wilk test. The $t$-test for independent samples was used to evaluate differences in variables between the two groups (ConG and IntG). A $t$-test for paired samples was performed for the Int $G$ at 
baseline and post-intervention. The threshold for statistical significance was set at $\mathrm{p}<0.05$.

\section{RESULTS}

The total sample has 34 participants: 26 males and 8 females. The mean age was $83.24 \pm 6.9$ years. There were no statistically differences observed in terms of age $(p=0.76)$, sex ( $p=0.69)$, or sedentary lifestyle $(p=1)$ between the ConG and IntG at the first evaluation.

Tables 1 and 2 show the data for muscle thickness (MT) and echo-intensity (EI) for each three quadriceps femoris heads and for the two groups and two sessions, respectively.

At the end of the eight weeks, only six participants of each group were available to undergo the post-intervention evaluation session.
For EI, VL had the highest values $(91.28 \pm 3.25$ a.u. for the right side and $98.31 \pm 9.00$ a.u. for the left side), and the VM had the lowest values $(70.25 \pm 11.56$ a.u. for the right side and $66.56 \pm 7.66$ a.u. for the left side). MT had a negative correlation with age and EI had a significant positive correlation with age. EI also had a significant negative correlation with MT.

There were no differences between the groups ( $\mathrm{p}<$ $0.05)$ for either measurement, MT or EI, at the baseline evaluation. However, comparing the two groups at post-evaluation, there were differences between the groups $(\mathrm{p}<0.05)$ for both measurements, MT and EI $(p<0.05)$., There were differences in EI values for right RF and VI muscles and left VM and VL muscles when comparing Int $\mathrm{G}$ at baseline and post-intervention $(\mathrm{p}<0.05)$.

Table 1. Data on muscle thickness ( $\mathrm{cm}$ ) measurements (baseline and post-intervention)*.

\begin{tabular}{l|c|c|c|c}
\hline Thickness $(\mathrm{cm})$ & \multicolumn{2}{|c|}{ Control Group } & \multicolumn{2}{c}{ Intervention Group } \\
\hline Muscles & $\begin{array}{c}1 \text { 1st session } \\
(\mathbf{n}=16)\end{array}$ & $\begin{array}{c}\text { 2nd session } \\
(\mathbf{n}=6)\end{array}$ & $\begin{array}{c}1 \text { 1st session } \\
(\mathbf{n}=18)\end{array}$ & $\begin{array}{c}\text { 2nd session } \\
(\mathbf{n}=6)\end{array}$ \\
\hline Right Side & $1.78 \pm 0.38$ & $1.78 \pm 0.38$ & $1.89 \pm 0.53$ & $1.95 \pm 0.29^{\mathrm{a}}$ \\
\hline Vastus medialis & $1.45 \pm 0.38$ & $1.45 \pm 0.38$ & $1.52 \pm 0.37$ & $1.18 \pm 0.31^{\mathrm{a}}$ \\
\hline Vastus lateralis & $1.15 \pm 0.37$ & $1.15 \pm 0.37$ & $1.19 \pm 0.3$ & $1.12 \pm 0.54^{\mathrm{a}}$ \\
\hline Rectus femoris & & & & \\
\hline Left Side & $1.74 \pm 0.55$ & $1.74 \pm 0.55$ & $2.06 \pm 0.70$ & $1.74 \pm 0.38^{\mathrm{a}}$ \\
\hline Vastus medialis & $1.35 \pm 0.32$ & $1.35 \pm 0.32$ & $1.46 \pm 0.36$ & $1.33 \pm 0.41^{\mathrm{a}}$ \\
\hline Vastus lateralis & $1.27 \pm 0.42$ & $1.27 \pm 0.42$ & $0.97 \pm 0.30$ & $1.09 \pm 0.42^{\mathrm{a}}$ \\
\hline Rectus femoris & & & & \\
\hline
\end{tabular}

*Data presented as mean \pm standard deviation; a significant difference between the control group and intervention group post-intervention $(p<0.05)$.

Table 2. Data of muscle echo-intensity (absent of unit [a.u.]) was measured using a rectangular ROI (baseline and post-intervention).

\begin{tabular}{l|c|c|c|c}
\hline Echo-Intensity (a.u.) & \multicolumn{2}{|c}{ Control Group } & \multicolumn{2}{c}{ Intervention Group } \\
\hline Muscles & $\begin{array}{c}1 \text { st session } \\
(\mathbf{n}=16)\end{array}$ & $\begin{array}{c}\text { 2nd session } \\
(\mathbf{n}=6)\end{array}$ & $\begin{array}{c}1 \text { st session } \\
(\mathbf{n}=18)\end{array}$ & $\begin{array}{c}\text { 2nd session } \\
(\mathbf{n}=6)\end{array}$ \\
\hline Right Side & $82.79 \pm 11.32$ & $82.60 \pm 11.02$ & $90.78 \pm 10.31$ & $70.25 \pm 11.56^{\mathrm{b}}$ \\
\hline Vastus medialis & $99.22 \pm 11.64$ & $98.99 \pm 12.00$ & $100.54 \pm 8.37$ & $91.28 \pm 3.25^{\mathrm{a}, \mathrm{b}}$ \\
\hline Vastus lateralis & $93.92 \pm 12.50$ & $93.50 \pm 12.00$ & $92.40 \pm 12.17$ & $85.21 \pm 11.70^{\mathrm{a}, \mathrm{b}}$ \\
\hline Rectus femoris & & & & \\
\hline Left Side & $85.09 \pm 11.7$ & $85.00 \pm 11.57$ & $85.09 \pm 8.49$ & $66.56 \pm 7.66^{\mathrm{a}}$ \\
\hline Vastus medialis & $101.07 \pm 12.44$ & $101.97 \pm 11.98$ & $103.09 \pm 9.78$ & $98.31 \pm 9.00^{\mathrm{a}, \mathrm{b}}$ \\
\hline Vastus lateralis & $92.74 \pm 10.77$ & $92.00 \pm 09.50$ & $92.61 \pm 13.65$ & $89.13 \pm 13.44^{\mathrm{a}, \mathrm{b}}$ \\
\hline Rectus femoris & & & & \\
\hline
\end{tabular}

*Data presented as mean \pm standard deviation; ${ }^{a}$ significant difference between the control group and intervention group post-intervention $(p<0.05)$; ${ }^{b}$ difference between the two sessions for the intervention group $(p<0.05)$. 


\section{DISCUSSION}

This study observed low MT values for all three heads of the quadriceps femoris, in the range of 1.0 and $2.1 \mathrm{~cm}$, respectively, for RF and VM. This is in line with other authors who reported MT values of around $1.4 \mathrm{~cm}$ for RF and $1.5 \mathrm{~cm}$ for VI. ${ }^{33-37}$

Other studies reported EI values around 66.30 a.u. for VM, 74.90 a.u. for VL, and 78.30 a.u. for $\mathrm{RF}^{36,38}$ which are lower than the values found in this study. This may be due to the age range, which was higher in this study. This may reflect the effects of aging and muscle changes on the participants, presenting increased connective and adipose tissue in muscles and reducing muscle mass (i.e., thickness).,139-42 However, compared with other studies with the same age range, EI values were similar, ${ }^{23,36,39}$ and our research may not have had enough power to detect statistically significant changes

As expected, younger populations showed higher values for MT, and lower values for EI. 12,17,41,43-46 There are also differences between the values when comparing active and sedentary older individuals, although these differences are smaller. ${ }^{10,24}$ Other authors suggested that older individuals with a lower age range have higher $\mathrm{MT}$ values and lower EI values. ${ }^{35,36,47,48}$

This study also found differences between EI measurements taken at the Int $\mathrm{G}$ pre and post-intervention assessments, finding lower values for $\mathrm{EI}$ post-intervention in the intervention group. Most of the literature confirms these results, showing that intervention programs involving physical activity provoke changes in muscle quality, reducing sarcopenia. ${ }^{1,23,37,42,49,50}$

According to Radaelli et al., ${ }^{51}$ physical activity decreases muscle echo-intensity, indicating a greater amount of contractile tissue. Studies reveal age-related changes in musculoskeletal composition, such as an increase in intramuscular adipose tissue, replacing contractile tissue, and reducing muscle mass, leading to an increase in the EI of the muscles of the upper and lower extremities. ${ }^{27,29,39,52}$

Regarding the EI of the muscle, there is an increase in intramuscular connective tissue and a decrease in the number of capillaries in aging. These changes will contribute to greater isolation of each capillary from the adjacent muscle fiber and reduced blood supply to muscle fibers, ${ }^{40,53}$ which may explain the increase in muscle echo-intensity in inactive older adult people.

Studies show that regular exercise leads to an increase in muscle vascularization, attenuating the effects of aging, which explains the decrease in muscle EI. ${ }^{29,40,53}$ Thus, the significant decrease in the EI of the right RF and VL and the left VM and VL muscles observed in this study after the physical intervention agrees with what is described in the literature, demonstrating, once again, that physical exercise attenuates the effects of aging and also that it brings benefits for many diseases and health disorders, including sarcopenia. ${ }^{27}$
However, this study did not find significant differences in MT, which is often suggested by the literature. ${ }^{34}$ These authors report that after older adults undergo a combined strength and endurance program, there are significant increases in muscle thickness, ${ }^{40}$ thus combating muscle mass loss associated with aging.

Sáez de Asteasu et al. ${ }^{54}$ claim that an individualized training program, with particular emphasis on muscle power training, was associated with improved lower limb muscle power output at submaximal loads and maximal muscle strength in older patients during acute hospitalization. Maybe the intervention used in this study should be reorganized and individualized to a greater extent to obtain more significant differences and gains in muscle mass, reducing sarcopenia.

This study has some limitations. This pilot study sampling was not randomized, and the researchers and participants were not masked to intervention during measurements. The loss to follow-up higher to $60 \%$ in both groups (initial sample size: 34:; final sample size: 12), compromising the tests' power. Potential confounders that might interfere with the US parameters were not controlled. However, considering included participants, those allocated to InG were motivated, yet some dropped out during the program.

\section{CONCLUSION}

This pilot study found some muscle changes using US parameters in older adults, suggesting an increase in muscle quality after a physical activity program. These results cannot be extrapolated to other older populations. Further studies should be performed to guarantee more robust results. These results suggest that muscle ultrasound parameters may be a low-cost objective method for muscle evaluation in older adults' physical activity programs assessment.

\section{ACKNOWLEDGMENTS}

A special acknowledgement to the entire AGA @ 4life project team.

\section{AUTHORS' CONTRIBUTION}

RS: conceptualization, data curation, formal analysis, writing - original draft, writing - review and editing.

HF: data curation, resources, writing — review and editing.

\section{CONFLICTS OF INTEREST}

The authors declare no conflicts of interest. 


\section{FUNDING}

This research is co-financed by the European Regional Development Fund (ERDF), through the partnership agreement Portugal 2020 - Regional Operation Program CENTRO2020, part of the project CENTRO-01-0145-FEDER-023369 AGA@4life: AGA - Comprehensive Geriatric approach to promote an active and healthy aging - implementation of an integrated and multidisciplinary intervention program.

\section{REFERENCES}

1. Moraes W, Souza P, Irigoyen M, Medeiros A, Koike M. Programa de exercícios físicos baseado em frequência semanal mínima : efeitos na pressão arterial e aptidão física em idosos hipertensos. Rev Bras Fisioter. 2011;15:1-8.

2. Rocha S. Efeitos do aumento da atividade física na funcionalidade e qualidade das pessoas idosas do Centro Social de Ermesinde. (Relatório de Estágio de Mestrado). 2012.

3. Fechine B, Trompieri N. O Processo de Envelhecimento: as principais alterações que acontecem com o idoso com o passar dos anos. Rev Científica Int. 2012;1(1):106-132.

4. Tribess S, Virtuoso J. Prescrição de Exercícios Físicos para Idosos. Rev Saúde Com. 2005;1(2):163-172.

5. Matsudo S, Keihan V, Matsudo R, Neto T. Impacto do envelhecimento nas variáveis antropométricas, neuromotoras e metabólicas da aptidão física. Rev Bras Ciência e Mov. 2000;8(4):21-32.

6. Cruz-Jentoft AJ, Bahat G, Bauer J, et al. Sarcopenia: Revised European consensus on definition and diagnosis. Age Ageing. 2019;48(1):1631. doi:10.1093/ageing/afy169

7. Emin M, Halil M, Kara Ö, Cuni B, Cankurtaran M, Özçakar L. Ultrasonographic evaluation of the calf muscle mass and architecture in elderly patients with and without sarcopenia. Arch Gerontol Geriatr. 2016;65:218-224. doi:10.1016/j.archger.2016.04.004

8. Cooper C, Dere W, Evans W, et al. Frailty and sarcopenia: definitions and outcome parameters. Osteoporos Int. January 2012:1839-1848. doi:10.1007/s00198-012-1913-1

9. O'Brien T, Reeves N, Baltzopoulos V, Jones D, Maganaris C. Muscletendon structure and dimensions in adults and children. J Anat. 2010;216(5):631-642. doi:10.1111/j.1469-7580.2010.01218.x

10. Gómez-Cabello A, Carnicero J a, Alonso-Bouzón C, et al. Age and gender, two key factors in the associations between physical activity and strength during the ageing process. Maturitas. 2014;78(02):106112. doi:10.1016/j.maturitas.2014.03.007

11. Santos R, Armada-da-Silva PAS. Reproducibility of ultrasound-derived muscle thickness and echo-intensity for the entire quadriceps femoris muscle. Radiography. 2017;23(3). doi:10.1016/j.radi.2017.03.011

12. Pillen S. Skeletal muscle ultrasound. Eur J Transl Myol. 2010;1(4):145155. doi: $10.1179 / 1743132811$ Y.0000000010

13. Santos R, Armada-da-silva PAS. Reproducibility of ultrasound-derived muscle thickness and echo-intensity for the entire quadriceps femoris muscle. Radiography. 2017:1-11. doi:10.1016/j.radi.2017.03.011

14. Santos R, Valamatos MJ, Mil-homens P, Armada-da-silva PAS. Muscle thickness and echo-intensity changes of the quadriceps femoris muscle during a strength training program. Radiography. 2018:1-10. doi:10.1016/j.radi.2018.03.010

15. Wakefield RJ, Balint P V, Szkudlarek M, et al. Musculoskeletal Ultrasound Including Definitions for Ultrasonographic Pathology. 2005:2485-2487.

16. Vlychou M, Teh J. Ultrasound of muscle. Curr Probl Diagn Radiol. 2008;37(5):219-230. doi:10.1067/j.cpradiol.2007.08.006

17. Valamatos MJ, Tavares F, Santos RM, Veloso AP, Mil-homens P. Influence of full range of motion vs. equalized partial range of motion training on muscle architecture and mechanical properties. 2018:3932

18. Narici M V, Maganaris CN. Adaptability of elderly human muscles and tendons to increased loading. J Anat. 2006;208(4):433-443. doi:10.1111/j.1469-7580.2006.00548.x
19. Pillen S, Keimpema M, Nievelstein R, Verrips A, Kruijsbergen-Raijmann W, Zwarts M. Skeletal muscle ultrasonography: Visual versus quantitative evaluation. Ultrasound Med Biol. 2006;32(9):1315-1321. doi:10.1016/j.ultrasmedbio.2006.05.028

20. Pillen S, Arts I, Zwarts M. Muscle ultrasound in neuromuscular disorders. Muscle Nerve. 2008;37(6):679-693. doi:10.1002/mus.21015

21. Nielsen P, Jensen B, Darvann T, Jørgensen K, Bakke M. Quantitative ultrasound tissue characterization in shoulder and thigh muscles--a new approach. BMC Musculoskelet Disord. 2006;7(2):1-11. doi:10.1186/1471-2474-7-2

22. Stringer HJ, Wilson D. The Role of Ultrasound as a Diagnostic Tool for Sarcopenia. J frailty aging. 2018;7(4):258-261. doi:10.14283/ jfa.2018.24

23. Yoshiko A, Tomita A, Ando R, et al. Effects of 10-week walking and walking with home-based resistance training on muscle quality, muscle size, and physical functional tests in healthy older individuals. Eur Rev Aging Phys Act. 2018;15(1):1-10. doi:10.1186/s1 1556-0180201-2

24. Chodzko-Zajko WJ, Proctor DN, Fiatarone Singh M a, et al. American College of Sports Medicine position stand. Exercise and physical activity for older adults. Med Sci Sports Exerc. 2009;41(7):1510-1530. doi:10.1249/MSS.0b013e3181a0c95c

25. Tavares A. Idosos e Actividade Física - programas, qualidade de vida e atitudes. (Tese de Mestrado). 2010.

26. De Mello RGB, Dalla Corte RR, Gioscia J, Moriguchi EH. Effects of Physical Exercise Programs on Sarcopenia Management, Dynapenia, and Physical Performance in the Elderly: A Systematic Review of Randomized Clinical Trials. J Aging Res. 2019;2019. doi:10.1155/2019/1959486

27. Steffl M, Bohannon RW, Sontakova L, Tufano JJ, Shiells K, Holmerova I. Relationship between sarcopenia and physical activity in older people: A systematic review and meta-analysis. Clin Interv Aging 2017;12:835-845. doi:10.2147/CIA.S132940

28. Mantovani E. Saúde Física, Indicadores Antropométricos, Desempenho Físico E Bem-Estar Subjetivo Em Idosos Atendidos No Ambulatório De Geriatria Do Hc/Unicamp - Atividade Física, Saúde e Envelhecimento. (Tese de Mestrado). 2007.

29. Lee SY, Tung HH, Liu CY, Chen LK. Physical Activity and Sarcopenia in the Geriatric Population: A Systematic Review. J Am Med Dir Assoc. 2018;19(5):378-383. doi:10.1016/j.jamda.2018.02.003

30. Argento R. Benefícios da atividade física na saúde e qualidade de vida do idoso. (Monografía de Bacharelato). 2010.

31. Martins AC, Guia D, Saraiva M, Pereira T. Effects of a "modified" otago exercise program on the functional abilities and social participation of older adults living in the community-the aga@4life model. Int Environ Res Public Health. 2020;17(4). doi:10.3390/ijerph17041258

32. Berger J, Bunout D, Barrera G, et al. Rectus femoris (RF) ultrasound for the assessment of muscle mass in older people. Arch Gerontol Geriatr. 2015;61(1):33-38. doi:10.1016/j.archger.2015.03.006

33. Strasser E, Draskovits T, Praschak M, Quittan M, Graf A. Association between ultrasound measurements of muscle thickness, pennation angle, echogenicity and skeletal muscle strength in the elderly. Age (Omaha). 2013;35(6):2377-2388. doi:10.1007/s11357-013-9517-z

34. Cadore E, Izquierdo M, Conceição M, et al. Echo intensity is associated with skeletal muscle power and cardiovascular performance in elderly men. Exp Gerontol. 2012;47(6):473-478. doi:10.1016/j. exger.2012.04.002 
35. Raj IS, Bird SR, Shield AJ. Reliability of ultrasonographic measurement of the architecture of the vastus lateralis and gastrocnemius medialis muscles in older adults. Clin Physiol Funct Imaging. 2012;32(1):65-70. doi:10.1111/j.1475-097X.2011.01056.x

36. Perkisas S, Baudry S, Bauer J, et al. Application of ultrasound for muscle assessment in sarcopenia: towards standardized measurements. Eur Geriatr Med. 2018;9(6):739-757. doi:10.1007/s41999-018-0104-9

37. Ticinesi A, Meschi T, Narici M V, Lauretani F, Maggio M. Muscle Ultrasound and Sarcopenia in Older Individuals: A Clinical Perspective. 2016. doi:10.1016/j.jamda.2016.11.013

38. Wilhelm E, Rech A, Minozzo F, Radaelli R, Botton C, Pinto R. Relationship between quadriceps femoris echo intensity, muscle power, and functional capacity of older men. Age (Omaha). 2014;4(Fev 11):1-6. doi:10.1007/s11357-014-9625-4

39. Fukumoto Y, Ikezoe T, Yamada Y, et al. Skeletal muscle quality assessed from echo intensity is associated with muscle strength of middleaged and elderly persons. Eur J Appl Physiol. 2012;112(4):1519-1525. doi:10.1007/s00421-011-2099-5

40. Cadore E, Pinto R, Bottaro M, Izquierdo M. Strength and Endurance Training Prescription in Healthy and Frail Elderly. Aging Dis. 2014;5(1):113.

41. Nishihara K, Kawai $\mathrm{H}$, Hayashi $\mathrm{H}$, et al. Frequency analysis of ultrasonic echo intensities of the skeletal muscle in elderly and young individuals. Clin Interv Aging. 2014;9:1471-1478. doi:10.2147/ CIA.S67820

42. Ticinesi A, Meschi T, Narici M V., Lauretani F, Maggio M. Muscle Ultrasound and Sarcopenia in Older Individuals: A Clinical Perspective. J Am Med Dir Assoc. 2017;18(4):290-300. doi:10.1016/j. jamda.2016.11.013

43. Verhulst F, Leeuwesteijn A, Louwerens J, Geurts A, Van Alfen N, Pillen S. Quantitative ultrasound of lower leg and foot muscles: feasibility and reference values. Foot ankle Surg. 2011;17(3):145149. doi:10.1016/j.fas.2010.04.002

44. Alegre L, Aznar D, Delgado T. Architectural characteristics of vastus lateralis muscle and jump performance in young men. J Hum .... 2005:1-13. http://www.uclm.es/profesorado/xaguado/INVESTIGACI?N/ articulos/pdfJHMSA.pdf.
45. Strasser EM, Draskovits T, Praschak M, Quittan M, Graf A. Association between ultrasound measurements of muscle thickness, pennation angle, echogenicity and skeletal muscle strength in the elderly. Age (Omaha). 2013;35(6):2377-2388. doi:10.1007/s11357-013-9517-z

46. Narici M V, Maganaris CN, Reeves ND, Capodaglio P. Effect of aging on human muscle architecture. J Appl Physiol. 2003;95(6):2229-2234. doi:10.1152/japplphysiol.00433.2003

47. Mcgregor RA, Cameron-smith D, Poppitt SD. It is not just muscle mass : a review of muscle quality, composition and metabolism during ageing as determinants of muscle function and mobility in later life. Longev Heal. 2014;3(9):1-8.

48. Nobili A, Garattini S, Mannucci PM. Multiple diseases and polypharmacy in the elderly : challenges for the internist of the third millennium. 2011:28-44.

49. Miranda A, Picorelli A, Pereira D, et al. Adherence of older women with strength training and aerobic exercise. Clin Interv Aging. 2014;9(Fev 14):323-331. doi:10.2147/CIA.S54644

50. Caporicci S, Neto MFO. Estudo comparativo de idosos ativos e inativos através da avaliação das atividades da vida diária e medição da qualidade de vida. Motricidade. 2011;7(2):15-24.

51. Radaelli R, Bottaro M, Wilhelm E, Wagner D, Pinto R. Time Course of Strength and Echo Intensity Recovery After Resistance Exercise in Women. J Strength Cond Res. 2012;26(9):2577-2584. https://www. ncbi.nlm.nih.gov/pubmed/22037095.

52. Thom JM, Morse Cl, Birch KM, Narici M V. Influence of muscle architecture on the torque and power-velocity characteristics of young and elderly men. Eur J Appl Physiol. 2007;100(5):613-619. doi:10.1007/s00421-007-0481-0

53. Cadore EL, González-Izal M, Pallarés JG, et al. Muscle conduction velocity, strength, neural activity, and morphological changes after eccentric and concentric training. Scand J Med Sci Sport. 2014:24(5):343-352. doi:10.1111/sms.12186

54. Sáez de Asteasu ML, Martínez-Velilla N, Zambom-Ferraresi F, et al. Changes in muscle power after usual care or early structured exercise intervention in acutely hospitalized older adults. J Cachexia Sarcopenia Muscle. 2020;1 1(4):997-1006. doi:10.1002/jcsm.12564 